\title{
CS-25 -Análisis del impacto económico en la producción del Café con denominación de origen en Chiapas
}

\author{
Analysis of the economic impact on the production of coffee with denomination \\ of origin in Chiapas \\ Yhadira Huicab García*, Raziel Esau Coop Abreu, Luis Alfredo Méndez Jiménez
}

División Académica de la Licenciatura en Administración, Instituto Tecnológico Superior de los Ríos, México

*Autora a quien se dirige la correspondencia: yhady_garcia@hotmail.com

\section{Resumen}

$\mathrm{E}$ n el presente proyecto de investigación se realiza un análisis económico enfocado a la producción de café con denominación de origen en Chiapas y sus impactos para las comunidades que se dedican a esta actividad, así como también se analizaran los factores que impactan en la producción como son el costo-beneficio de las semillas, roya del cafeto y el impacto de estos en la producción. Esta investigación se integra al proyecto de investigación denominado "Desarrollo, evaluación en campo y análisis de factibilidad comercial de dos cultivos del sureste mexicano con denominación de origen editado genómicamente para conferirles resistencia contra patógenos fúngicos y oomicetos", siendo la fuente de financiamiento la "Comisión Intersecretarial de Bioseguridad de los Organismos Genéticamente Modificados (Cibiogem)", con una vigencia de febrero 2017 a febrero 2020, en donde el responsable es José Juan Zuñiga Aguilar. La colaboración que se desarrolla en este proyecto es la determinación del análisis costo-beneficio, desarrollo del modelo de negocios de los cultivos genéticamente modificados, así como la evaluación comercial y transferencia del modelo del negocio a productores. Las variedades silvestres del cafeto a estudiar son las siguientes café arábigo, café robusta, café liberiano y café excelso. El proyecto de investigación se encuentra en su primera etapa, donde se recopila información y se realiza el análisis del costo-beneficio de la implementación de las variedades de cafeto, así como el diseño del instrumento de medición, aplicación de prueba piloto, así como la validación y confiabilidad por expertos.

Palabras claves: Análisis económico, costo-beneficio, producción, café, Chiapas

\section{Abstract}

$\mathrm{I}_{\mathrm{t} i \mathrm{~s}}^{\mathrm{n}}$

$\mathrm{n}$ the present research project an economic analysis is carried out focused on the production of coffee with denomination of origin in Chiapas and its impacts for the communities that are dedicated to this activity, as well as the factors that impact on the production as they are the cost-benefit of the seeds, coffee rust and the impact of these on production. This research is part of the research project entitled "Development, field evaluation and commercial feasibility analysis of two crops in the Southeast of Mexico with a genomically edited designation of origin to confer resistance against fungal pathogens and oomycetes", the source of funding being the "Commission Intersecretarial of Biosafety of Genetically Modified Organisms (Cibiogem) “, with a validity from February 2017 to February 2020, where the person in charge is Dr. José Juan Zuñiga Aguilar. The collaboration that develops in this project is the determination of the cost - benefit analysis, development of the business model of the genetically modified crops, as well as the commercial evaluation and transfer of the business model to producers. The wild varieties of coffee to be studied are the following Arabica coffee, robusta coffee, Liberian coffee and excelso coffee. The research project is in its first stage, where information is collected and the cost - benefit analysis of the implementation of the coffee varieties is carried out, as well as the design of the measurement instrument, the application of the pilot test, as well as the validation and reliability by experts.

Key words: Economic analysis, cost-benefit, production, coffee, Chiapas 